\title{
Carbon and Metal(loid)s in Parkland and Road Verge Surface Soils in the City of Liverpool, UK
}

\author{
Luke Beesley ${ }^{1, *}$, Eduardo Moreno-Jiménez ${ }^{2}$, Phil Jenn $^{3}$ and Nicholas W. Lepp ${ }^{4}$ \\ 1 The James Hutton Institute, Craigiebuckler, Aberdeen AB15 8QH, UK \\ 2 Universidad Autónoma de Madrid, 28049 Madrid, Spain; eduardo.moreno@uam.es \\ 3 Private Practice, 20 Muirend Road, Cardross G82 5LG, UK; phil.jenn@abc.uk \\ 4 Private Practice, 35 Victoria Road, Formby L37 7DH, UK; nick.lepp@formby.net \\ * Correspondence: luke.beesley@hutton.ac.uk
}

Received: 31 January 2020; Accepted: 26 February 2020; Published: 2 March 2020

\begin{abstract}
Urban soils are at the interface between land and people and provide a wide variety of important ecosystem services to highly populous areas. The aims of this soil survey were (1) to measure the bulk density, carbon (C) storage and $\mathrm{pH}$ of surface soils $(0-15 \mathrm{~cm}$ depth) from public spaces (parks and road verges) in the city of Liverpool, UK, and (2) to determine the likely impact of these master variables on heavy metal concentrations ( $\mathrm{As}, \mathrm{Cd}, \mathrm{Cu}, \mathrm{Pb}$ and $\mathrm{Zn}$ ). The bulk densities and organic matter contents varied considerably in the predominantly sandy textured soils within the city boundary, resulting in diverse $C$ densities from $1-10 \mathrm{~kg} \mathrm{C} \mathrm{m}^{2}$. Organic carbon formed the majority of the labile, water-soluble and extractable $\mathrm{C}$ pool in these soils, a fact not easily elucidated from their organic matter or $\mathrm{C}$ content alone. The copper and lead concentrations in the sampled soils were correlated with organic matter and organic carbon in water-extracts. Cadmium and zinc appeared to be dependent only on soil $\mathrm{pH}$, whilst arsenic was related positively to organic matter, but negatively to $\mathrm{pH}$. Interrelationships, and hence synonymous distributions, of all metal(loid)s existed, but were strongest between $\mathrm{Cu}$ and $\mathrm{As}$, and $\mathrm{Cu}$ and $\mathrm{Pb}$. These results suggest that the diverse bulk densities, and hence carbon storage, of the urban soils surveyed influenced the dispersal of metals and arsenic.
\end{abstract}

Keywords: urban soils; carbon sequestration; bulk density; heavy metals

\section{Introduction}

Land use in urban areas is transient and rapidly changing on decadal timescales with the constant cycle of development. Often containing large amounts of coarse material [1], many urban soils have been augmented or deepened through past waste disposal [2,3] reflecting short term change and large-scale heterogeneity. In urban topsoils, the physico-chemical characteristics and concentrations of trace elements have been shown to vary considerably over relatively small geographical scales and between centres of urbanization $[4,5]$. Likewise, previous studies have also reported variable carbon storage in urban soils [6-11]. Notwithstanding their large variability, urban soils are increasingly recognized as having the potential to store more carbon (C) than agricultural or 'natural' soils [12]. For example, Vasenev and Kuzyakov [13], compiling data from over 700 urban soils, revealed that $\mathrm{C}$ accumulation in urban soils extended far greater in depth than in 'natural' soils, resulting in a net 3- to 5 -fold greater $C$ storage in the urban than in the 'natural' soils sampled. Some urban soils have been found to contain twice as much organic carbon in the upper $30 \mathrm{~cm}$ of soil than below this depth, because unlike neighbouring agricultural soils, urban topsoils are less likely to have been as regularly and systematically worked [14], and conditions conducive to the accumulation of C are extant.

Physico-chemical interactions between the organic matter in soils and metal(loid)s may also influence the distribution of contaminants in soils. Parry et al. [15] surveyed 200 samples across 
the county of Merseyside (greater Liverpool area), finding that $\mathrm{Pb}$ and $\mathrm{Zn}$ hotspots correlated with the general extent of urbanization, whilst $\mathrm{Cu}$ and $\mathrm{Cd}$ were localized, and mainly associated with the industrial emission of particulates and associated dispersal and deposition [16,17], which is not surprising in this formerly industrially active region. Further investigation into the transport of metal(loid)s through local soil profiles in this region indicated that the mobility of metal(loid)s is strongly correlated with water-soluble carbon $[18,19]$. Thus, it follows that urban soils in formerly industrialized areas may exhibit strong correlations of contaminants within hotspots of $C$ rich soils.

The aim of this study was to evaluate the extent to which urban public parkland and road verge topsoils in the city of Liverpool varied in their key properties. The bulk density and organic matter were determined for 92 soils, whilst a subset of 52 were analysed in more detail to determine their labile, water-soluble pool of $C$, and concentration and association of trace metals and arsenic with other soil properties. The interrelationships between soil properties and metal(loid)s are discussed, with specific reference to the management of urban soils.

\section{Study Sites and Methods}

\subsection{Sampling Locations and Soil Sampling}

A total of 92 topsoils (0-15 cm depth) were sampled from urban parklands and road verges within the city boundaries of Liverpool, UK. Sampling locations were identified according to the least likelihood of recent soil disturbance (i.e., without any form of obvious tillage, disturbance, or addition or subtraction of material). At each sampling location, a 6-figure grid reference was taken using a Garmin Etrex handheld GPS in order to map the locations and ensure good coverage of the whole city during the rolling sampling. The sample locations and extent of city coverage are shown in Figure 1a, and location of the study area within the UK (Figure 1b). A free survey method was preferable here, rather than a grid scheme, because of the obvious ubiquity of sealed surfaces within the city environment (Figure 1c). By this method, soils were obtained away from paths, roads and other through routes, and newly created green spaces were avoided because soils could have been recently disturbed, imported or otherwise improved. Road verge samples were taken in areas where vehicles had not been parked, roadworks debris had not been dumped or where other clearly obvious recent disturbances had not occurred.

At each location, a sample of topsoil was taken by inserting and carefully withdrawing a steel triaxial cylinder, $2.5 \mathrm{~cm}$ in diameter and $20 \mathrm{~cm}$ in length, into the top $15 \mathrm{~cm}$ of soil. After the sample was taken, the ends of the cylinder were capped, and the samples were returned to the laboratory for analysis. 


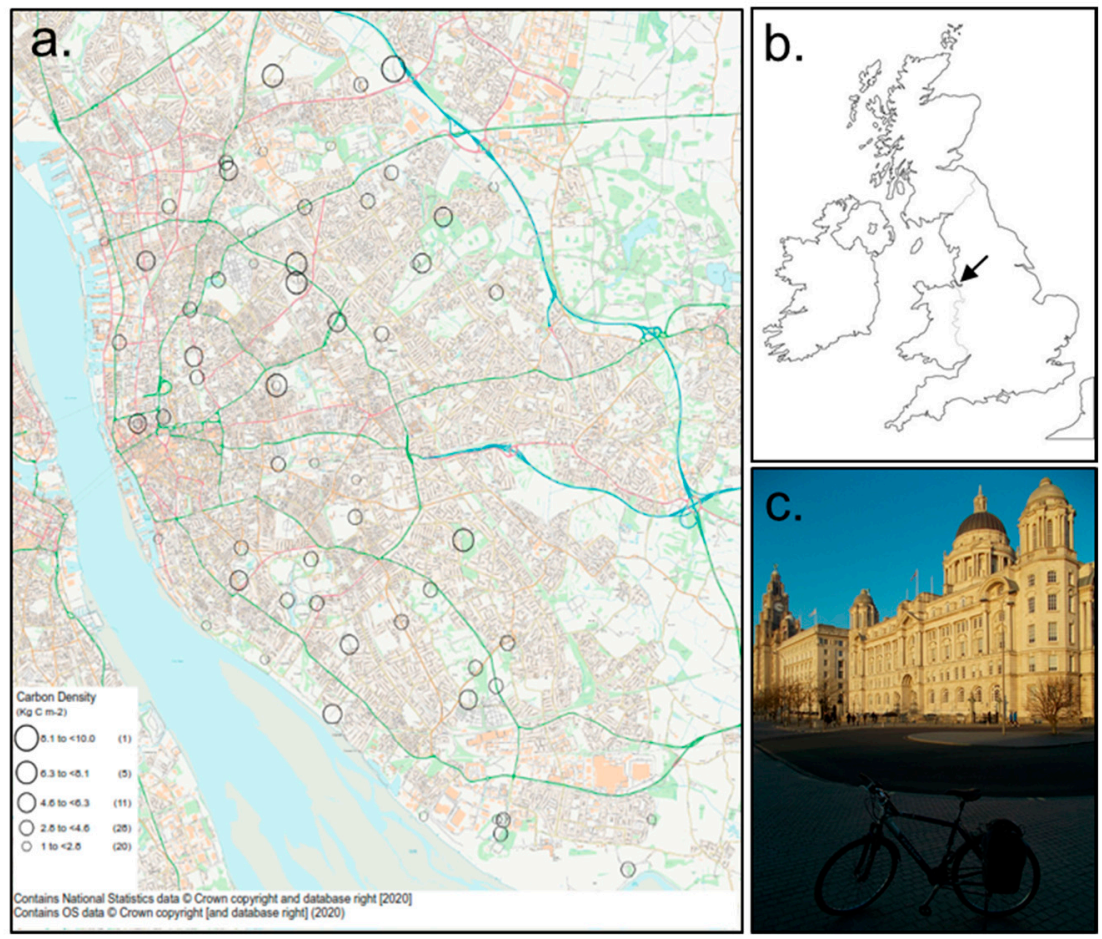

Figure 1. (a) Sample locations, selected by free survey, displaying the carbon (C) density of soils $(n=92)$. (b) The location of the study area within the UK (shown not to scale) and (c) the difficulty in locating soils in some areas due to the extent of sealed surfaces.

\subsection{Sample Preparation and Analysis}

Once at the laboratory the soil samples were divided into two for analyses, with all of the samples collected $(n=92)$ analysed for organic matter and bulk density, whilst a subset $(n=52)$ were additionally analysed for $\mathrm{pH}$, soil texture, total organic carbon, water-soluble total and organic carbon, water-soluble total nitrogen and metal(loid) concentrations. This was done due to the time constraints of analysing all samples for all parameters.

All samples $(n=92)$ : Bulk density (BD) was determined by measuring the volume/mass of air-dried soil (20-25 ${ }^{\circ} \mathrm{C}$ for $48 \mathrm{~h}$ ) in each cylinder. Soil was then lightly crushed and sieved to $<2 \mathrm{~mm}$. Organic matter (OM) was determined by the loss on ignition method (LOI), whereby the difference in air-dried soil mass and soil mass after heating to $550{ }^{\circ} \mathrm{C}$ was calculated.

Subset $(n=52)$ : The particle size distribution was determined using a Beckman Coulter LS 13 Laser Diffraction Particle Size Analyser: $2 \mathrm{~mm}-63 \mu \mathrm{m}$ (sand), 62.9-2 $\mu \mathrm{m}$ (silt) and $<2 \mu \mathrm{m}$ (clay). Owing to the relatively low organic matter content of the soils, organic matter was not removed prior to particle size analysis. Total (TC) and inorganic carbon (IC) were determined using a TOC-SSM (Shimadzu, Tokyo, Japan), and total organic carbon (TOC) was subsequently calculated as TC minus IC. Soil pH was measured in a 1:10 soil and de-ionised water ( $\mathrm{pH}$ 5.5) suspension, shaken for $3 \mathrm{~h}$ in an orbital shaker and allowed to settle for $45 \mathrm{~min}$. After $\mathrm{pH}$ analysis, the suspension was centrifuged at $3000 \mathrm{rpm}$ for $10 \mathrm{~min}$, and the resulting supernatant was passed through a nylon filter to remove any suspended particulate matter that could interfere with analysis. These sample extracts were analysed for total water-soluble carbon (WSTC), water-soluble organic carbon (WSOC) and water-soluble total nitrogen (WSTN) using a TOC-VE (Shimadzu, Tokyo, Japan).

The pseudo-total concentrations of trace elements were determined after the microwave-assisted digestion of $0.2 \mathrm{~g}$ air-dried soil samples $(<2 \mathrm{~mm})$ in concentrated $14 \mathrm{M}$, GPR grade $\mathrm{HNO}_{3}$, by ICP-MS (XSERIES 2 ICP-MS; Thermo Scientific, Waltham, MA, USA). Rhodium (1 ppm) was added to each sample as an internal standard, to compensate for the varying instrument responses during analysis. 


\subsection{Data Analysis and Mapping}

Soil carbon storage, hereafter referred to as soil $\mathrm{C}$ density, was determined using a conversion factor of organic matter to total organic carbon (TOC), calculated on the subset of samples on which both analyses had been carried out $(n=52)$. Firstly, the TOC for all samples was calculated by applying this conversion factor to the organic matter data for all samples $(n=92)$. The soil C densities $(\mathrm{kg} C$ $\mathrm{m}^{2}$ ) were then calculated according to the bulk density $\left(\mathrm{g} \mathrm{cm}^{3}\right)$ and TOC content $(\%)$ based on the soil sampling depth $(15 \mathrm{~cm})$.

To explore and simplify the interpretation of the resulting data, principal component analysis was run. This is a recognised tool to analyse complex and interrelated data sets [20] and was used in this study to evaluate the interrelationships between measured parameters. All statistical analyses were carried out in SPSS v.14 for Windows. The mapping, as shown in Figure 1a, was produced in MapInfo Pro 15.2.

\section{Results}

\subsection{Physico-Chemical Characteristics and C Storage}

The soils were predominantly sandy, loamy sand or sandy loam $(64 \%-94 \%$ sand), with low clay content $(<3.5 \%$; data not shown). An initial visual inspection of the soils in the field revealed that, unlike soils subject to considerable annual litter inputs, these soils contained no visible $\mathrm{O}$ (organic) horizon, probably reflecting the large degree of continuous management in the urban environment; the removal of litter and regular mowing and removal of grass, for example. Nonetheless, the soil $\mathrm{pH}$ varied considerably from $\mathrm{pH} 4-8$, as did bulk density $\left(<0.6\right.$ to $>1.8 \mathrm{~g} \mathrm{~cm}^{3}$; Figure 2), reflecting the variability of soil compaction. Organic matter contents had a mean of $8.2 \%$ (Figure 2) and the carbon densities ranged from c. 1-10 kg C m${ }^{2}$ city-wide; with 45 samples having $C$ densities of $1-4.5 \mathrm{~kg} \mathrm{C} \mathrm{m}^{2}$; and of those, 20 having $\mathrm{C}$ densities of $<2.8 \mathrm{~kg} \mathrm{C} \mathrm{m}^{2}$ (Figure 1a).
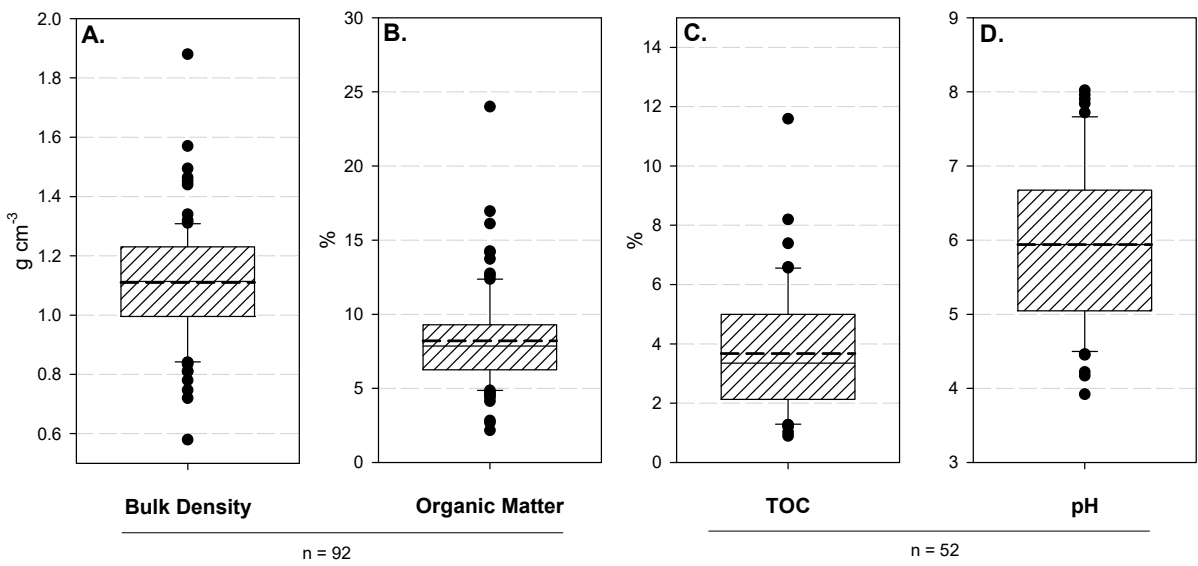

Figure 2. The mean and range of selected properties of urban soils (A and $\mathbf{B}$ from all samples, $\mathbf{C}$ and $\mathbf{D}$ from a subset of 52 samples). The dashed line is the mean value, the solid line is the median, the box represents the upper and lower quartiles, and the whiskers are the 10th and 90th percentiles.

Water-soluble total carbon (WSTC) was not substantially greater in concentration than mean water-soluble organic carbon (WSOC; Figure 3), leaving only a small soluble inorganic fraction. 


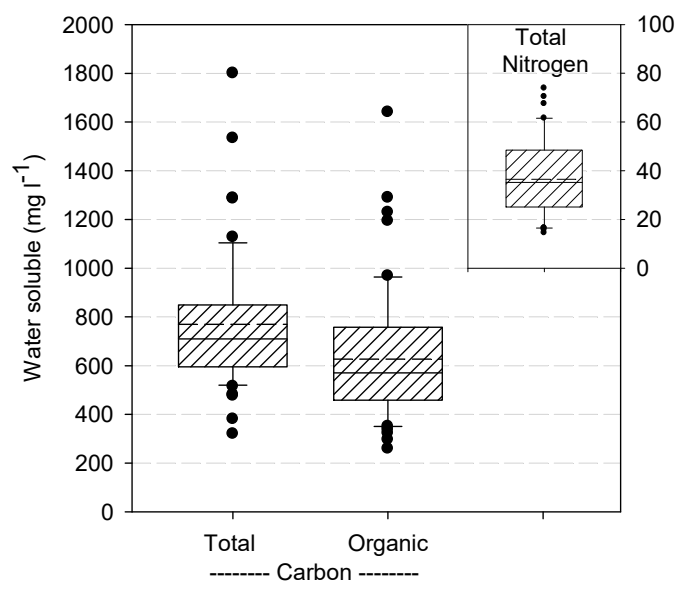

Figure 3. The mean and range of water-soluble total and organic carbon, and water-soluble total nitrogen (inset), taken from the aqueous extraction of a subset of surveyed urban soils $(n=52)$. The dashed line is the mean value, the solid line is the median, the box represents the upper and lower quartiles, and the whiskers are the 10th and 90th percentiles.

\subsection{Metal(loid) Concentrations}

Zinc and $\mathrm{Pb}$ were found at the highest mean pseudo-total concentrations in the sampled soils, followed by $\mathrm{Cu}$, As and $\mathrm{Cd}$ (Figure 4). The range of concentrations of all elements was large, reflecting the wide spatial distribution of the source samples, and general heterogeneous nature of these urban soils.
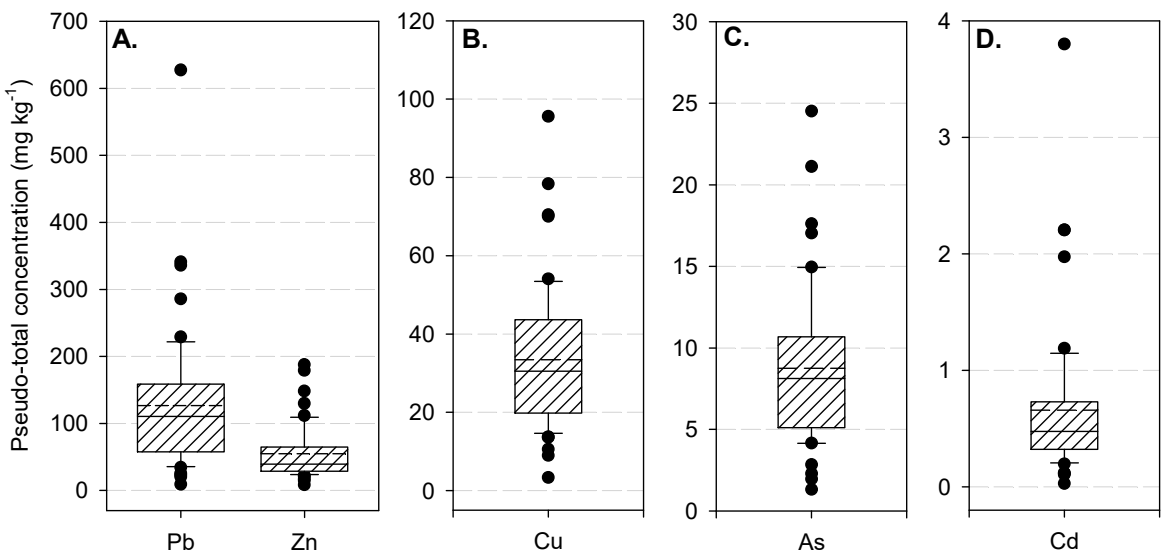

Figure 4. The mean and range of trace element pseudo-total concentrations in a subset of surveyed urban soils $(n=52)$. The dashed line is the mean value, the solid line is the median, the box represents the upper and lower quartiles, and the whiskers are the 10th and 90th percentiles.

\section{Discussion}

\subsection{Carbon Storage and Flux}

Carbon storage in soils is determined by the balance of bulk density and C content, with the trade-off between these factors resulting in increases or decreases in soil $\mathrm{C}$ density. The range of carbon densities of the soils of Liverpool (Figure 1a) was consistent with those of previous urban soil studies [6-8,21] that typically report $1.5-18 \mathrm{~kg} \mathrm{C} \mathrm{m}^{2}$. Interestingly, Beesley [22] reported that manufactured urban soils, composed of green waste compost and recycled mineral materials, displayed soil C densities of 2-12 $\mathrm{kg} \mathrm{C} \mathrm{m}^{2}$, similar to those recorded here. This demonstrates the impact of site management on soil $\mathrm{C}$ storage, in relation to the removal and/or addition of extraneous organic matter. 
Therefore, the capacity of some urban soils to accumulate $C$ is surprisingly high when compared to agricultural or native soils [12]. This fact is exemplified in a comprehensive review of urban soil C stocks, whereby more than 700 individual datapoints were analysed, concluding that urban soils accumulate $\mathrm{C}$ rapidly, resulting in their projected contribution to global soil $\mathrm{C}$ stocks being approx. $7 \%-13 \%$ [13]. It follows, therefore, that urban soils may also shed C rapidly.

Water-soluble carbon is an important constituent of the $C$ pool in soils because of its mobility and reactivity, and its capability to influence physical, biological and chemical processes in soil [23]. The lack of fresh organic inputs to many of the unmanaged soils of Liverpool goes some way to explaining the low water-soluble nitrogen concentration, and therefore the wide range of $C$ to $N$ ratios (23:1 to 55:1). In circum-neutral, well drained soils, a $C$ to $N$ ratio of 10:1 could typically be expected, [24] and the lack of $\mathrm{N}$ addition to the soils sampled here would undoubtedly limit the decomposition of $\mathrm{C}$, due to a lack of available labile substrate for micro-organisms to feed on. The fact that WSOC was not substantially lower in concentration than WSTC could indicate either (i) that the carbonate constituent of this soil was minimal/insoluble, or (ii) that the organic constituent was highly humified, recalcitrant and not easily extractable. Once again, managed urban soils (i.e., allotments) are likely to exhibit a more active pool of carbon, in the form of water-soluble carbon, especially when subject to recent or repeated additions of organic amendments [25]. Hence, more compacted and less worked/managed urban soils would appear to have the greatest potential for stable $C$ storage.

\subsection{Trace Metals and As}

Soil surveys of urban soils in other European cities have indicated, as was the case in Liverpool, that the concentrations of surface metal(loid)s are highly variable. Madrid et al. [5] sampled 63 soils across three cities and found higher $\mathrm{Zn}$ and $\mathrm{Pb}$ concentrations, compared to other measured elements, in two out of three cities (at up to $210 \mathrm{mg} \mathrm{kg}^{-1}$ and $237 \mathrm{mg} \mathrm{kg}^{-1} \mathrm{Zn}$ and $\mathrm{Pb}$ respectively byAqua Regia digestion). Ruiz-Cortes et al. [26] similarly measured total metal concentrations in 51 soils from 0-10 $\mathrm{cm}$ depth, also including urban areas of Seville, Spain, finding that $\mathrm{Zn}$ and $\mathrm{Pb}$ were present in the greatest concentrations, at up to $137 \mathrm{mg} \mathrm{kg}^{-1}$ and $725 \mathrm{mg} \mathrm{kg}^{-1}$ respectively, with Cd concentrations of $0.18-4.85 \mathrm{mg} \mathrm{kg}^{-1}$ also recorded. The soils of Liverpool are within these ranges. It follows that, just as $C$ densities are highly variable due to the array of measured bulk densities, thence the same physical property will manifest in vast differences in the of mass of metal(loid) per unit area of soil; soil contaminant loadings expressed in these terms are, as far as we can ascertain, seldom considered, but evidently highly environmentally relevant to discrete, small but well-worked patches of urban land.

\subsection{Interrelationships between Soil Parameters}

It is possible that the carbon budget of soils can be directly related to, and influential upon, the concentration and distribution of some trace elements. Principal component analysis is employed here to indicate interrelationships and shows that $\mathrm{As}, \mathrm{Cu}$ and $\mathrm{Pb}$ in the soils of Liverpool were positively related to organic matter and TOC (Table 1), which would indicate their stability and immobility, related to retention by organic matter; the strong affinity of $\mathrm{Cu}$ and $\mathrm{Pb}$ for organic matter in soils [27-32] and the retention of As by organic matter in soil [33] are well documented. However, organic materials can also release As to labile fractions [34], so that at times of high rainfall, which is the case in the maritime climate of Liverpool [18], increased mobility of this metalloid may be seen. It is also possible that the relatively high WSOC content of the soils (Figure 3) would influence the co-mobilization of metals and As associated with lighter organic fractions in the soil.

The zinc and $\mathrm{Cd}$ concentrations in the surveyed soils were not linked to organic matter or TOC, but rather to $\mathrm{pH}$ (Table 1). Both metals present similarities, from the chemical point of view and in their dynamics in soils, with their source often linked to human activities [34]. The strong mobility of both metals at $\mathrm{pH}<5$ is well known [35,36], as is their retention in the soil matrix at $\mathrm{pH}>5$ [37]. Thus, their association is quite different to that of $\mathrm{As}, \mathrm{Cu}$ and $\mathrm{Pb}$. Given that the surveyed soils had a mean $\mathrm{pH}$ of 6 (Figure 2), the mobility of $\mathrm{Zn}$ and $\mathrm{Cd}$ is likely not to be as strong as those of $\mathrm{As}, \mathrm{Cu}$ and $\mathrm{Pb}$. 
The maritime climate of the study area may also have influenced soil Na concentrations, which were not measured here, with attendant consequences for $\mathrm{pH}$ and electrical conductivity that may render $\mathrm{Cd}$ and $\mathrm{Zn}$ less mobile than would otherwise be expected.

Table 1. Principal component analysis of the measured parameters from 52 urban soil samples. Data were standardized before analysis. The cumulative total explained $67 \%$ of the variance, with the remaining $33 \%$ attributable to external factors not measured in this study (factors with loadings higher than 0.6 were included in this analysis).

\begin{tabular}{ccc}
\hline Factor & Component 1 (43\%) & Component 2 (24\%) \\
\hline Bulk Density & -0.63 & - \\
TOC & 0.74 & - \\
OM & 0.64 & - \\
pH & - & 0.81 \\
As & 0.90 & - \\
Cd & - & 0.60 \\
Cu & 0.89 & - \\
Pb & 0.75 & - \\
Zn & - & 0.70 \\
\hline
\end{tabular}

\section{Conclusions}

Sampled urban parkland and road verge topsoils in the city of Liverpool had C densities of

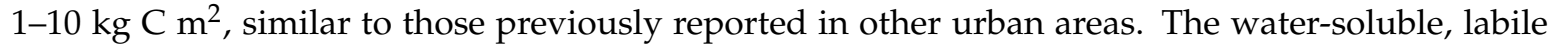
pool of carbon was predominantly organic, which, given the associations of some metal(loid)s with C, could impact negatively on their retention in soils over the longer term. Given the diversity of factors impacting the disturbance, compaction and augmentation of soils in urban areas, the results of this study in context add to the growing body of evidence that urban soils are diverse entities, hitherto overlooked as 'soils in their own right'. The range ofmetal(loid) concentrations and heterogeneous bulk densities of the soils sampled also suggest that potential contaminant hotspots may be extant where soils are rich in metal(loid)s and carbon, and also have high bulk densities. Those with responsibility for the stewardship of urban soils should therefore consider their varied and highly heterogeneous bulk densities and carbon contents, not only their metal(loid) concentration and other chemical parameters, when planning for changes of usage (for example, from parklands to allotments).

Author Contributions: L.B. and P.J. carried out the soil sampling and laboratory analysis. P.J. additionally provided mapping expertise and produced mapping output, whilst E.M.-J. was responsible for the statistical analysis. N.W.L. provided expert knowledge and guidance in the interpretation of soils data. L.B. carried out all writing and editing of the paper. All authors have read and agreed to the published version of the manuscript.

Funding: This research received no external funding.

Acknowledgments: The authors greatly appreciate the help of Shaun Sparke to complete the soil survey.

Conflicts of Interest: The authors declare no conflict of interest.

\section{References}

1. Schleuß, U.; Wu, Q.; Blume, H.-P. Variability of soils in urban and periurban areas in Northern Germany. Catena 1998, 33, 255-270.

2. Davidson, D.A.; Dercon, G.; Stewart, M.; Watson, F. The legacy of past urban waste disposal on local soils. J. Archaeol. Sci. 2006, 33, 778-783. [CrossRef]

3. He, Y.; Zhang, G.-L. Comments on 'Biochemical characterization of urban soil profiles from Stuttgart, Germany' by Klaus Lorenz and Ellen Kandeler. Soil Biol. Biochem. 2006, 38, 413-414. [CrossRef]

4. Madrid, L.; Diaz-Barrientos, E.; Madrid, F. Distribution of heavy metal contents of urban soils in parks in Seville. Chemosphere 2002, 49, 1301-1308. [CrossRef] 
5. Madrid, F.; Reinoso, R.; Florido, M.C.; Diaz-Barrientos, E.; Ajmone-Marsan, F.; Davidson, C.M.; Madrid, L. Estimating the extractability of potentially toxic metals in urban soils: A comparison of several extracting solutions. Environ. Pollut. 2007, 147, 713-722. [CrossRef] [PubMed]

6. Jo, H.-K.; McPherson, G.E. Carbon storage and flux in urban residential greenspace. J. Environ. Manag. 1995, 45, 109-133. [CrossRef]

7. Pouyat, R.; Groffman, P.; Yesilonis, I.; Hernandez, L. Soil Carbon pools and fluxes in urban ecosystems. Environ. Pollut. 2002, 116, 107-118. [CrossRef]

8. Pouyat, R.V.; Yesilonis, I.D.; Nowak, D.J. Carbon storage in urban soils in the United States. J. Environ. Qual. 2006, 35, 1566-1575. [CrossRef]

9. Pouyat, R.V.; Yesilonis, I.D.; Golubiewski, N.E. A comparison of soil organic carbon stocks between residential turf grass and native soil. Urban Ecosyst. 2009, 12, 45-62. [CrossRef]

10. Kaye, J.P.; McCulley, R.L.; Burke, I.C. Carbon fluxes, nitrogen cycling, and soil microbial communities in adjacent urban, native and agricultural ecosystems. Glob. Chang. Biol. 2005, 11, 575-587. [CrossRef]

11. Golubiewski, N.E. Urbanization increases grassland carbon pools: Effects of landscaping in Colorado's front range. Ecol. Appl. 2006, 16, 555-571. [CrossRef]

12. Pouyat, R.; Szlavecz, K.; Yesilonis, I.D.; Groffman, P.M.; Schwarz, K. Chemical, physical, and biological characteristics of urban soils. In Urban Ecosystem Ecology; Aitkenhead-Peterson, J., Volder, A., Eds.; American Society of Agronomy: Madison, WI, USA, 2010.

13. Vasanev, V.; Kuzyakov, Y. Urban soils as hot spots of anthropogenic carbon accumulation: Review of stocks, mechanisms and driving factors. Land Degrad. Dev. 2018, 29, 1607-1622. [CrossRef]

14. Morisada, K.I.; Ono, K.; Kanomata, H. Organic carbon stocks in forest soils in Japan. Geoderma 2004, 119, 21-32. [CrossRef]

15. Parry, G.D.R.; Johnson, M.S.; Bell, R.M. Trace metal surveys of soil as a component of strategic and local planning policy development. Environ. Pollut. 1981, 2, 97-107. [CrossRef]

16. Watmough, S.A.; Dickinson, N.M. Dispersal and mobility of heavy metals in relation to tree survival in an aerially contaminated woodland soil. Environ. Pollut. 1995, 90, 135-142. [CrossRef]

17. Lepp, N.W.; Hartley, J.; Toti, M.; Dickinson, N.M. Patterns of soil copper contamination in the vicinity of a copper rod rolling factory. Environ. Pollut. 1997, 95, 363-369. [CrossRef]

18. Beesley, L.; Dickinson, N. Carbon and trace element mobility in an urban soil amended with greenwaste compost. J. Soils Sediments 2010, 10, 215-222. [CrossRef]

19. Beesley, L.; Dickinson, N. Carbon and trace element fluxes in the pore water of an urban soil following greenwaste compost, woody and biochar amendments, inoculated with the earthworm Lumbricus terrestris. Soil Biol. Biochem. 2011, 43, 188-196. [CrossRef]

20. Sena, M.M.; Frighetto, R.T.S.; Valarini, P.J.; Tokeshi, H.; Poppi, R.J. Discrimination of management effects on soil parameters by using principal component analysis: A multivariate analysis case study. Soil Tillage Res. 2002, 67, 171-181. [CrossRef]

21. Tomlinson, R.W.; Milne, R.M. Soil carbon stocks and land cover in Northern Ireland from 1939 to 2000. Appl. Geogr. 2006, 26, 18-39. [CrossRef]

22. Beesley, L. Carbon storage and fluxes in existing and newly created urban soils. J. Environ. Manag. 2012, 104, 158-165. [CrossRef] [PubMed]

23. Scaglia, B.; Adani, F. Biodegradability of soil water soluble carbon extracted from seven different soils. J. Environ. Sci. 2009, 21, 641-646. [CrossRef]

24. White, R.E. Principles and Practices of Soil Science: The Soil as a Natural Resource; Blackwell: London, UK, 1997.

25. Beesley, L. Respiration $\left(\mathrm{CO}_{2}\right.$ flux) from urban and peri-urban soils amended with green waste compost. Geoderma 2014, 223, 68-72. [CrossRef]

26. Ruiz-Cortes, E.; Reinoso, R.; Diaz-Barrientos, E.; Madrid, L. Concentrations of potentially toxic metals in urban soils of Seville: Relationship with different land uses. Environ. Geochem. Health 2005, 27, 465-474. [CrossRef]

27. Miller, W.P.; McFee, W.W. Distribution of cadmium, zinc, copper, and lead in soils of industrial northwestern Indiana. J. Environ. Qual. 1983, 12, 29-33. [CrossRef]

28. Blaylock, M.J.; Salt, D.E.; Dushenkov, S.; Zakharova, O.; Gussman, C.; Kapulnik, Y.; Ensley, B.D.; Raskin, I. Enhanced Accumulation of $\mathrm{Pb}$ in Indian Mustard by Soil-Applied Chelating Agents. Environ. Sci. Technol. 1997, 31, 860-865. [CrossRef] 
29. Sauvé, S.; McBride, M.B.; Norvell, W.A.; Hendershot, W.H. Copper Solubility and Speciation of In Situ Contaminated Soils: Effects of Copper Level, pH and Organic Matter. Water Air Soil Pollut. 1997, 100, 133-149. [CrossRef]

30. Zhang, M.K.; Ke, Z.-X. Copper and Zinc Enrichment in Different Size Fractions of Organic Matter from Polluted Soils. Pedosphere 2004, 14, 27-36.

31. Clemente, R.; Bernal, M.P. Fractionation of heavy metals and distribution of organic carbon in two contaminated soils amended with humic acids. Chemosphere 2006, 64, 1264-1273. [CrossRef]

32. Thums, C.R.; Farago, M.E.; Thornton, I. Bioavailability of trace metals in brownfield soils in an urban area in the UK. Environ. Geochem. Health 2008, 30, 549-563. [CrossRef]

33. Gadepalle, V.P.; Ouki, S.K.; Van Herwijnen, R.; Hutchings, T. Immobilization of heavy metals in soil using natural and waste materials for vegetation establishment on contaminated sites. Soil Sediments Contam. 2007, 16, 233-251. [CrossRef]

34. Hartley, W.; Dickinson, N.M.; Clemente, R.; French, C.; Piearce, T.G.; Sparke, S.; Lepp, N.W. Arsenic stability and mobilization in soil at an amenity grassland overlying chemical waste (St. Helens, UK). Environ. Pollut. 2009, 157, 847-856. [CrossRef] [PubMed]

35. Adriano, D.C. Trace Elements in Terrestrial Environments. In Biogeochemistry, Bioavailability and Risks of Metals, 2nd ed.; Springer: New York, NY, USA, 2001; 866p.

36. Ross, S.M. Toxic Metals in Soil-Plant Systems; John Wiley \& Sons: Chichester, UK, 1994.

37. Kabata-Pendias, A. Soil-plant transfer of trace elements-an environmental issue. Geoderma 2004, 122, $143-149$. [CrossRef]

(C) 2020 by the authors. Licensee MDPI, Basel, Switzerland. This article is an open access article distributed under the terms and conditions of the Creative Commons Attribution (CC BY) license (http://creativecommons.org/licenses/by/4.0/). 